\title{
Caridina variabilirostris (Crustacea: Decapoda: Atyidae), a new species of freshwater shrimp from Pohnpei (Micronesia)
}

\author{
Valentin de MAZANCOURT ${ }^{1, *}$, Gerard MARQUET ${ }^{2} \&$ Philippe KEITH $^{3}$ \\ 1,2,3 Muséum national d'Histoire naturelle, Département Adaptations du Vivant, UMR 7208, CP026, \\ 57, rue Cuvier, 75231 Paris, Cedex 05, France. \\ *Corresponding author: valentin.demazancourt@laposte.net \\ ${ }^{2}$ Email: gmarquet@neuf.fr \\ ${ }^{3}$ Email: keith@mnhn.fr \\ ${ }^{1}$ urn:1sid:zoobank.org:author:1DC1FC86-2988-4EDF-8FC1-053CCD6C06FF \\ ${ }^{2}$ urn:lsid:zoobank.org:author:BB110358-4FA2-4F5B-BF3A-B51F69D81AA9 \\ ${ }^{3}$ urn:lsid:zoobank.org:author:FDDE84AB-E459-401C-A9BF-3F16CEEBFD7C
}

\begin{abstract}
Recently, the status of a new species of atyid shrimp from Pohnpei (Micronesia) was discussed in relation to C. brachydactyla De Man, 1908 and C. mertoni J. Roux, 1911. By combining morphological data with a phylogenetic analysis with closely related species, this species is here described as Caridina variabilirostris sp. nov. Notes on its ecological distribution are also provided. The new species is characterized by a highly variable rostrum and is present in rivers all over Pohnpei Island. The status of this new species is clarified and it is shown that neither C. brachydactyla De Man 1908 nor C. mertoni J. Roux, 1911 occur on Pohnpei Island.
\end{abstract}

Keywords. 16S, molecular, integrative taxonomy, island, morphology.

Mazancourt V. de, Marquet G. \& Keith P. 2018. Caridina variabilirostris (Crustacea: Decapoda: Atyidae), a new species of freshwater shrimp from Pohnpei (Micronesia). European Journal of Taxonomy 453: 1-16.

https://doi.org/10.5852/ejt.2018.453

\section{Introduction}

Micronesia is a vast expanse of more than 2000 Pacific islands and atolls stretching from the Caroline and Mariana Islands in the West, to the Marshall, Nauru and Kiribati Islands in the East. The Caroline Islands consist of a chain of seamounts, atolls and high islands extended southeastward to the Marshall Islands. The high island of Pohnpei (formely known as Ponape) is situated at $6^{\circ} 54^{\prime} \mathrm{N}$ latitude and $158^{\circ} 14^{\prime}$ E longitude (Fig.1). It belongs to Pohnpei State, one of the four states in the Federated State of Micronesia. The island of Pohnpei covers $345 \mathrm{~km}^{2}$. The highest elevation point is $791 \mathrm{~m}$. Aged of 8.7 Ma, this volcanic island was not only the remnant of a hotspot trace, but was also produced in a fracture-induced subduction-related tectonic environment (Rehman et al. 2013). 
The freshwater shrimp genus Caridina Milne Edwards, 1837, comprising 298 species (WoRMS database, as of May 2018) and mostly present in the Indo-Pacific region, is the most diversified genus of the Atyidae (De Grave et al. 2015) and an important ecological component in the tropical streams (Covich et al. 1999; Pringle et al. 1993). Its high diversity combined with the lack of informative morphological characters has led to a confused taxonomy (Richard \& Clark 2009). Indeed, until recently, the taxonomy of the genus was mainly based on morphological characters. Some of those have been proven highly variable within a species (e.g., rostrum shape and indentation or coloration) and so taxonomically non-informative, making it difficult to establish boundaries between species (Rintelen \& Cai 2009; Mazancourt et al. 2017). Thus, there is a need for an integrative and standardized approach to improve the group's systematics, focusing on informative morphological features and using molecular characters (Page et al. 2005; Page \& Hughes 2011).

Maciolek \& Ford (1987) recorded Caridina brachydactyla De Man, 1908 among seven species of Atyidae in rivers on Pohnpei. Later, this species was not collected either by Nelson et al. (1996) or by Buden et al. (2001). Keith et al. (2012), reviewing the decapods of Ponhpei, conducted a freshwater survey from 7 to 17 March 2012, identified the material of Caridina belonging to the complex of C. nilotica as C. brachydactyla or C. mertoni Roux, 1911 (following the previous identifications made from Guam, another Micronesian island, by Leberer \& Cai 2003).

One of the aims of the Muséum national d'Histoire naturelle (MNHN) in Paris is to carry out faunistic inventories of rivers in tropical islands in order to establish a better protection of these fragile ecosystems and, in this context, to clarify taxonomy of poorly known organisms. As we examined more and more specimens from Pohnpei, we gradually started to question the validity of some species from this island. Consequently, we here re-examined our specimens collected in 2012 in combining morphological data with a $16 \mathrm{~S}$ mtDNA analysis and found that neither C. brachydactyla nor C. mertoni occur in Pohnpei, but have been confused until now with one undescribed species. Recently, Mazancourt et al. (2017) highlighted the "Pinocchio-shrimp effect", in this species, which has a variable length of the rostrum depending on the altitude.

Detailed description of this new species is given as well as its ecological distribution. The position of this species is clarified by comparing it with C. brachydactyla and C. mertoni.

\section{Material and methods}

\section{Abbreviations for collections}

MNHN = Muséum national d'Histoire naturelle, Paris

$\mathrm{NHM}=$ Natural History Museum, London

$\mathrm{NMB}=$ Naturhistorisches Museum Basel, Basel

RMNH $=$ Rijksmuseum van Natuurlijke Historie (now the Naturalis Biodiversity Center, Leiden)

$\mathrm{WK}=$ Werner Klotz's collection

ZRC = Zoological Reference Collection, National University of Singapore, Singapore

\section{Abbreviations for morphological analyses}

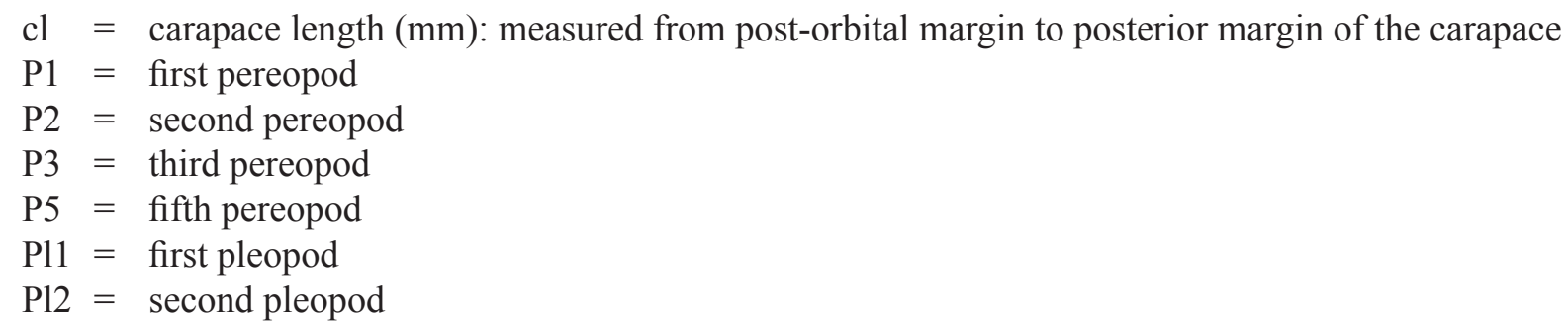




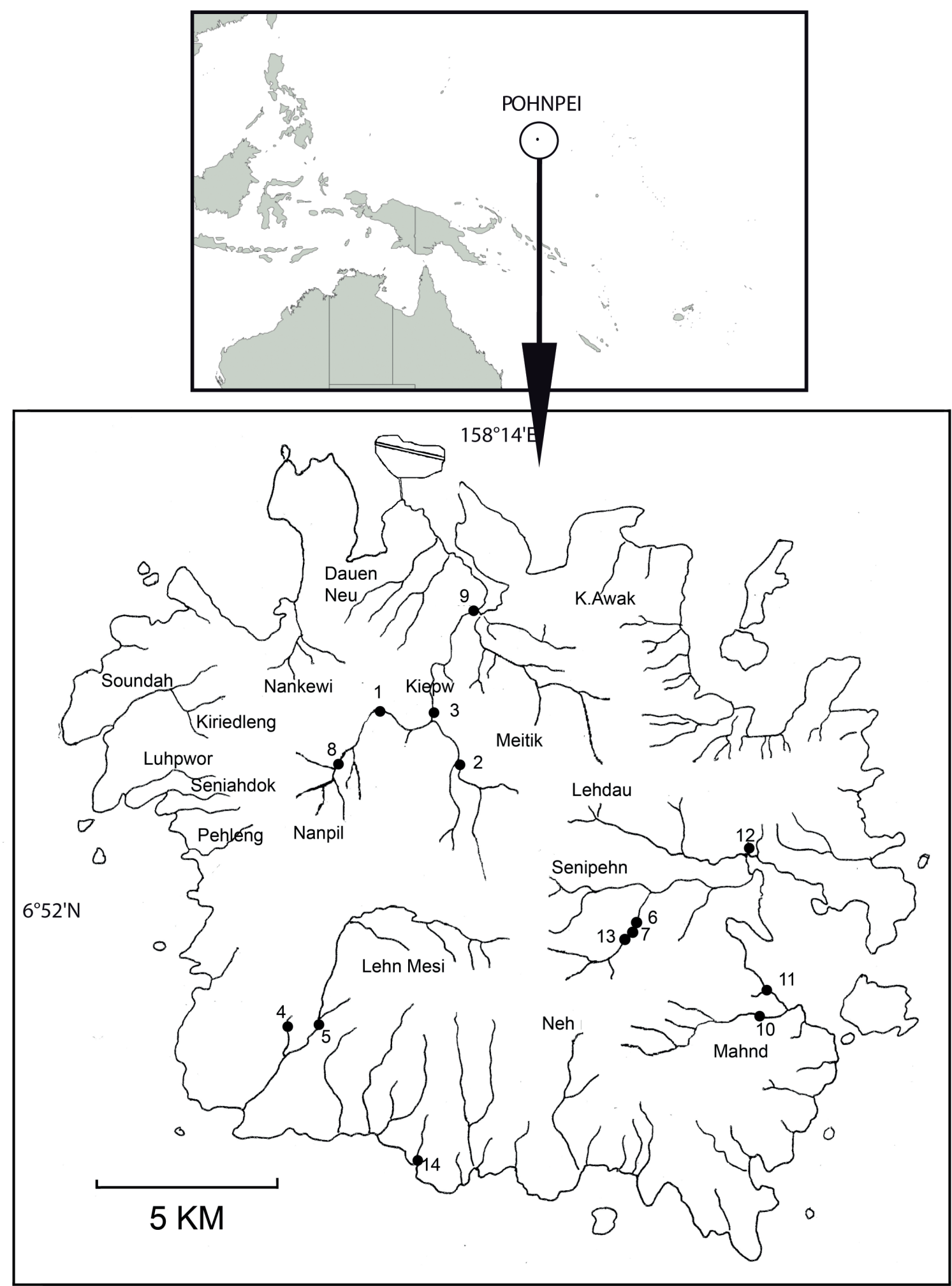

Fig. 1. Map of Pohnpei Island showing sampling stations (black dots) with their number (refers to Table 1). 
Table 1. Sampling localities data.

\begin{tabular}{ccccc}
\hline & Dates & Coordinates & Rivers & Altitude (m) \\
\hline Station 1 & 9 Mar. 2012 & $06^{\circ} 55.242^{\prime} \mathrm{N}, 158^{\circ} 12.265^{\prime} \mathrm{E}$ & Nanpil & 127 \\
Station 2 & 9 Mar. 2012 & $06^{\circ} 54.498^{\prime} \mathrm{N}, 158^{\circ} 13.270^{\prime} \mathrm{E}$ & Nanpil & 93 \\
Station 3 & 9 Mar. 2012 & $06^{\circ} 55.111^{\prime} \mathrm{N}, 158^{\circ} 12.878^{\prime} \mathrm{E}$ & Nanpil & 52 \\
Station 4 & 10 Mar. 2012 & $06^{\circ} 51.055^{\prime} \mathrm{N}, 158^{\circ} 10.890^{\prime} \mathrm{E}$ & Lehn Mesi & 197 \\
Station 5 & 10 Mar. 2012 & $06^{\circ} 51.107^{\prime} \mathrm{N}, 158^{\circ} 11.896^{\prime} \mathrm{E}$ & Lehn Mesi & 139 \\
Station 6 & 12 Mar. 2012 & $06^{\circ} 51.895^{\prime} \mathrm{N}, 158^{\circ} 15.810^{\prime} \mathrm{E}$ & Senipehn & - \\
Station 7 & 12 Mar. 2012 & $06^{\circ} 51.906^{\prime} \mathrm{N}, 158^{\circ} 16.010^{\prime} \mathrm{E}$ & Senipehn & 95 \\
Station 8 & 13 Mar. 2012 & $06^{\circ} 54.252^{\prime} \mathrm{N}, 158^{\circ} 11.491^{\prime} \mathrm{E}$ & Nanpil & 180 \\
Station 9 & 13 Mar. 2012 & $06^{\circ} 56.609^{\prime} \mathrm{N}, 158^{\circ} 13.550^{\prime} \mathrm{E}$ & Nanpil estuary & 5 \\
Station 10 & 14 Mar. 2012 & $06^{\circ} 50.221^{\prime} \mathrm{N}, 158^{\circ} 17.212^{\prime} \mathrm{E}$ & Mahnd & 107 \\
Station 11 & 14 Mar. 2012 & $06^{\circ} 51.120^{\prime} \mathrm{N}, 158^{\circ} 17.854^{\prime} \mathrm{E}$ & "River 1" estuary & 5 \\
Station 12 & 14 Mar. 2012 & $06^{\circ} 53.221^{\prime} \mathrm{N}, 158^{\circ} 17.44^{\prime} \mathrm{E}$ & "Petroglyphe River" & 5 \\
Station 13 & 15 Mar. 2012 & $06^{\circ} 51.795^{\prime} \mathrm{N}, 158^{\circ} 15.622^{\prime} \mathrm{E}$ & Senipehn & 119 \\
Station 14 & 10 Mar. 2012 & $06^{\circ} 48.579^{\prime} \mathrm{N}, 158^{\circ} 12.639^{\prime} \mathrm{E}$ & "River 2" estuary & 5 \\
\hline
\end{tabular}

\section{Collection of specimens}

Rivers and sites surveyed in March 2012 are indicated in Figure 1 and Table 1. Specimens from Pohnpei were collected by electrofishing (portable Dekka 3000 electric device, Germany). All material preserved in $75 \%-95 \%$ alcohol has been deposited in the collections of the Muséum national d'Histoire naturelle in Paris (MNHN, specimens $n^{\circ}$ MNHN-IU-2018-231 to MNHN-IU-2018-256).

\section{DNA extraction, amplification and sequencing}

For recent specimens, DNA was extracted from abdominal tissues using the semi-automatic Eppendorf ep-Motion 5075 robot. Fragments of the mitochondrial 16S rRNA ( $520 \mathrm{bp})$ were amplified using the primers 16Sa-L (CGCCTGTTTATCAAAAACAT) and 16Sb-H2 (CTCCGGTTTGAACTCAGATCA) (Palumbi 1996). DNA amplification was performed in $25 \mu$ PCR reactions, containing approximately $3 \mathrm{ng}$ of template DNA, $2.5 \mathrm{mM} \mathrm{MgCl}, 0.26 \mathrm{mM}$ of each nucleotide, $0.3 \mu \mathrm{M}$ of each primer, $5 \% \mathrm{DMSO}$, $1 \mathrm{ng}$ of BSA and 1.5 units of QBIOTAQ polymerase (MPBiomedicals). Amplification products were generated by an initial denaturation step of $4 \mathrm{~min}$ at $94^{\circ} \mathrm{C}$ followed by 35 cycles of denaturation at $94^{\circ} \mathrm{C}$ for $30 \mathrm{~s}$, annealing at $52^{\circ} \mathrm{C}$ for $40 \mathrm{~s}$, extension at $72^{\circ} \mathrm{C}$ for $60 \mathrm{~s}$ and a final extension step at $72^{\circ} \mathrm{C}$ for $7 \mathrm{~min}$.

For old collection specimens (syntypes of $C$. mertoni), a CTAB protocol was used to extract DNA from pleopods. A shorter fragment of the $16 \mathrm{~S}$ rRNA ( $332 \mathrm{bp}$ ) was amplified using two newly designed primers: 16S-Car-81F (AGGTAGCATAATAAATAGTC) and 16S-Car-413R (CTGTTATCCCTAAAGTAAC). 
DNA amplification was performed in $25 \mu$ PCR reactions, containing $2.5 \mathrm{mM} \mathrm{MgCl}, 0.26 \mathrm{mM}$ of each nucleotide, $0.3 \mu \mathrm{M}$ of each primer, $1 \mathrm{ng}$ of BSA and 1.5 units of QBIOTAQ polymerase (MPBiomedicals). Amplification products were generated by an initial denaturation step of 4 min at $94^{\circ} \mathrm{C}$ followed by 45 cycles of denaturation at $94^{\circ} \mathrm{C}$ for $30 \mathrm{~s}$, annealing at $55^{\circ} \mathrm{C}$ for $30 \mathrm{~s}$, extension at $72^{\circ} \mathrm{C}$ for $40 \mathrm{~s}$ and a final extension step at $72^{\circ} \mathrm{C}$ for $7 \mathrm{~min}$.

PCR products were sequenced using the same primers and in both directions to insure the accuracy of base calls. Chromatograms were edited using Geneious v. 8 software (Kearse et al. 2012). All sequences were deposited in GenBank (Numbers MH476222 to MH476227). A sequence retrieved from GenBank for Paratya australiensis published by Page et al. (2007) was included in our analysis, used as outgroup.

A total of 17 recent specimens were sequenced (Table 2): six of the new species, of which two firstly identified as $C$. brachydactyla with a long rostrum and four as $C$. mertoni with a short rostrum; five of $C$. mertoni from Kolombangara Island; three type specimens of $C$. variabilis Mazancourt, Rogers \& Keith, 2018 and three of $C$. brachydactyla from the type locality, Sulawesi. In addition, three old collection specimens, syntypes of C. mertoni from Kai Island were included (Mazancourt et al. 2018).

\section{Molecular analyses}

DNA sequences were aligned using MEGA7 software (Kumar et al. 2016) with Muscle algorithm (Edgar 2004). Using Bayesian information criterion in PartitionFinder (Lanfear et al. 2012), we retained the HKY + G + I model. Best-scoring Maximum Likelihood (ML) trees were estimated using RAxML HPC2 v. 8.2.10 (Stamatakis 2014) implemented in the Cyber Infrastructure for Phylogenetic Research (CIPRES) portal v. 3.1. (Miller et al. 2010). One hundred independent searches, each starting from

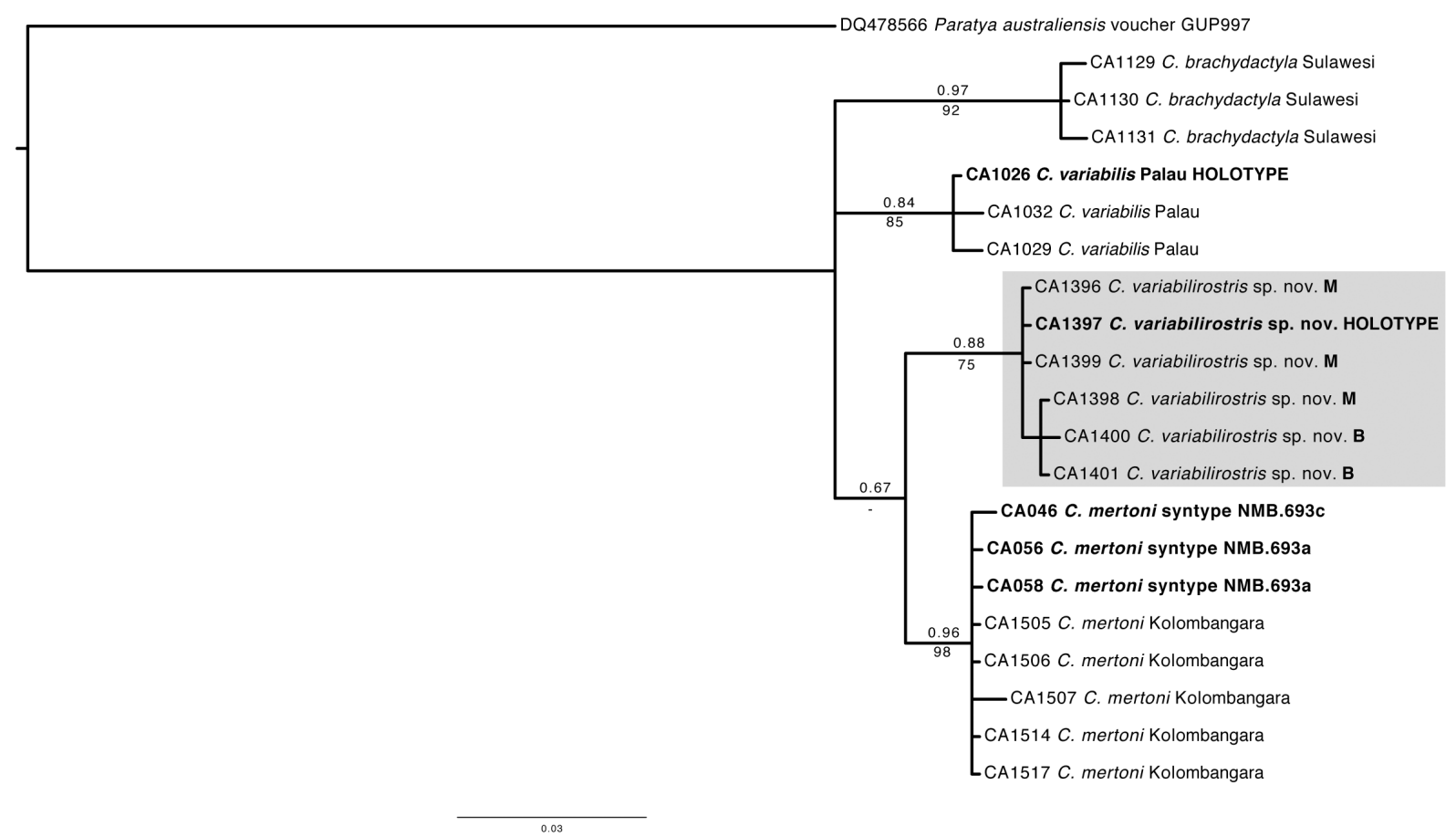

Fig. 2. Neighbour-Joining tree of the $16 \mathrm{~S}$ sequences of the specimens. Numbers on branches indicate bootstrap values. Letters ' $\mathrm{M}$ ' indicate specimens firstly identified as Caridina mertoni and letters 'B' indicate specimens firstly identified as Caridina brachydactyla. 
Table 2. Specimens used in the genetic analysis.

\begin{tabular}{llllll}
\hline Specimen $\mathbf{n}^{\circ}$ & Species & Locality & Firstly ident. as & GenBank n & Reference \\
\hline CA1396 & C. variabilirostris & Pohnpei (St. 1) & C. mertoni & MH476222 & this study \\
CA1397 & C. variabilirostris & Pohnpei (St. 8) & C. mertoni & MH476223 & this study \\
CA1398 & C. variabilirostris & Pohnpei (St. 8) & C. mertoni & MH476224 & this study \\
CA1399 & C. variabilirostris & Pohnpei (St. 8) & C. mertoni & MH476225 & this study \\
CA1400 & C. variabilirostris & Pohnpei (St. 9) & C. brachydactyla & MH476226 & this study \\
CA1401 & C. variabilirostris & Pohnpei (St. 9) & C. brachydactyla & MH476227 & this study \\
CA1026 & C. variabilis & Palau & & MG707146 & Mazancourt et al. 2018 \\
CA1029 & C. variabilis & Palau & & MG707148 & Mazancourt et al. 2018 \\
CA1032 & C. variabilis & Palau & & MG707147 & Mazancourt et al. 2018 \\
CA1129 & C. brachydactyla & Indonesia & & MG707169 & Mazancourt et al. 2018 \\
CA1130 & C. brachydactyla & Indonesia & & MG707170 & Mazancourt et al. 2018 \\
CA1131 & C. brachydactyla & Indonesia & & MG707171 & Mazancourt et al. 2018 \\
CA046 & C. mertoni & Indonesia & & MG707138 & Mazancourt et al. 2018 \\
CA056 & C. mertoni & Indonesia & & MG707139 & Mazancourt et al. 2018 \\
CA058 & C. mertoni & Indonesia & & MG707140 & Mazancourt et al. 2018 \\
CA1505 & C. mertoni & Solomon Islands & & MG707141 & Mazancourt et al. 2018 \\
CA1506 & C. mertoni & Solomon Islands & & MG707142 & Mazancourt et al. 2018 \\
CA1507 & C. mertoni & Solomon Islands & & MG707143 & Mazancourt et al. 2018 \\
CA1514 & C. mertoni & Solomon Islands & MG707144 & Mazancourt et al. 2018 \\
CA1517 & C. mertoni & Solomon Islands & MG707145 & Mazancourt et al. 2018 \\
GUP997 & Paratya & Australia & DQ478566 & Page et al. 2007 \\
& australiensis & & & \\
\hline
\end{tabular}

distinct random trees, were conducted. Robustness of the nodes was assessed using non-parametric bootstrapping (Felsenstein 1985) with 1000 bootstrap replicates. Best-scoring Bayesian Inference trees were estimated using MrBayes v. 3.2.6 (Ronquist \& Huelsenbeck 2003) also implemented in CIPRES with the previously determined model, running for 10000000 generations, a sampling frequency of 2000 and a burn in of $25 \%$. Support for nodes was determined using posterior probabilities calculated by MrBayes.

\section{Morphological comparison}

The rostrum, general cephalon, pereopods 1, 2, 3 and 5 and abdomen were observed using a stereoscopic microscope. The proportions of the various joints of the appendages were measured using microphotographs and AnalySIS Works software (Olympus). Drawings were made using the "Digital Inking" method (Coleman 2003, 2006) by tracing vectorial paths on stacks of high-resolution photographs using Adobe Illustrator (CS6) and a WACOM MPTZ-1230 graphic tablet.

\section{Results}

\section{Collection of specimens}

About 50 specimens were collected by electro-fishing in the different rivers prospected in Pohnpei. Of these, 26 were sequenced, 18 with a short rostrum and eight with a long one. A representative sample of six specimens is shown here in the genetic study. 


\title{
Phylogenetic analyses
}

After checking that consensus trees obtained from the two different methods were congruent, we decided to show the Bayesian consensus tree with both the ML bootstrap values and Bayesian posterior probabilities on branches. The specimens are grouped in four distinct and moderately supported clades. The most basal comprises the specimens of C. brachydactyla from Sulawesi (type locality), then, the type specimens of $C$. variabilis and, finally, two sister clades, one comprising recent and old specimens of $C$. mertoni and the other the specimens from Pohnpei. Due to the low support values, we cannot discuss the affinities of the different species, but we can confidently assert that the terminal clades are distinct species and consider the last one to be a new species that we describe below.

\section{Taxonomy}

\author{
Class Malacostraca Latreille, 1802 \\ Order Decapoda Latreille, 1802 \\ Family Atyidae De Haan, 1849 \\ Genus Caridina H. Milne Edwards, 1837 \\ Caridina variabilirostris sp. nov. \\ urn:1sid:zoobank.org:act:63F36D6C-9049-4D5E-902E-D38A3BCA3B0A
}

Figs 3-4

\section{Etymology}

The new species is named variabilirostris for its variable rostrum length.

\section{Material examined}

Holotype

POHNPEI (Station 8): ô , cl 3.5 mm, Nanpil river, $06^{\circ} 54.252^{\prime} \mathrm{N}, 158^{\circ} 11.491^{\prime} \mathrm{E}, 180 \mathrm{~m}$ a.s.1., 13 Mar. 2012 (MNHN-IU-2018-231, DNA: CA1397).

\section{Paratypes}

POHNPEI - Nanpil river (Station 1): 1 đ , cl $3.2 \mathrm{~mm}, 06^{\circ} 55.242^{\prime} \mathrm{N}, 158^{\circ} 12.265^{\prime} \mathrm{E}, 127 \mathrm{~m}$ a.s.1., 9 Mar. 2012, (MNHN-IU-2018-232); 1 , , cl 4.6 mm, same data as for preceding (MNHN-IU-2018-233); 1 o ovig., cl $4.1 \mathrm{~mm}$, same data as for preceding (MNHN-IU-2018-234, DNA: CA1396). - Nanpil

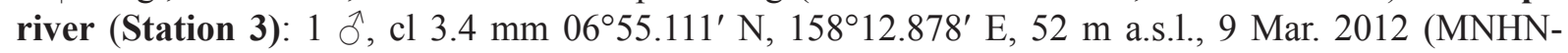
IU-2018-235); 1 + ovig., cl $4.5 \mathrm{~mm}$, same data as for preceding (MNHN-IU-2018-236). - Lehn Mesi river (Station 5): 2 + 9 , cl $4.7 \mathrm{~mm}$ (MNHN-IU-2018-237) and $4.8 \mathrm{~mm}$ (MNHN-IU-2018-238); 1 ㅇ ovig., cl 4.7 mm (MNHN-IU-2018-239), 0651.107' N, 158 $11.896^{\prime}$ E, 139 m a.s.1., 10 Mar. 2012. - Senipehn river (Station 7): 1 $, 06^{\circ} 51.906^{\prime} \mathrm{N}, 158^{\circ} 16.010^{\prime} \mathrm{E}, 95 \mathrm{~m}$ a.s.1., 12 Mar. 2012, cl $4.4 \mathrm{~mm}$ (MNHN-IU-2018-240); 2 우, ovig., cl. $4.1 \mathrm{~mm}$ (MNHN-IU-2018-241) and $4.5 \mathrm{~mm}$ (MNHNIU-2018-242), same data as for preceding. - Nanpil river (Station 8): $3 \hat{\partial} \hat{\partial}$, cl $3.4 \mathrm{~mm}$ (MNHNIU-2018-243, DNA: CA1399), $3.5 \mathrm{~mm}$ (MNHN-IU-2018-244) and $3.6 \mathrm{~mm}$ (MNHN-IU-2018-245, DNA: CA1398), $06^{\circ} 54.252^{\prime} \mathrm{N}, 158^{\circ} 11.491^{\prime} \mathrm{E}, 180 \mathrm{~m}$ a.s.1., 13 Mar. 2012; 1 \%, cl $4.4 \mathrm{~mm}$ (MNHNIU-2018-246), same data as for preceding; 1 o ovig., cl $5.1 \mathrm{~mm}$ (MNHN-IU-2018-247), same data as

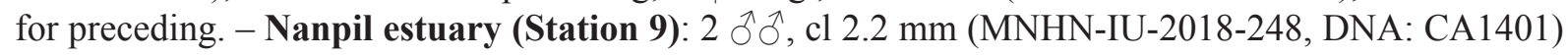
and $2.7 \mathrm{~mm}$ (MNHN-IU-2018-249), 06 ${ }^{\circ} 56.609^{\prime} \mathrm{N}, 158^{\circ} 13.550^{\prime} \mathrm{E}, 5 \mathrm{~m}$ a.s.1., 13 Mar. 2012; 2 우, $3.5 \mathrm{~mm}$ (MNHN-IU-2018-250, DNA: CA1400) and $3.7 \mathrm{~mm}$ (MNHN-IU-2018-251), same data as for preceding; 2 우 $ᄋ$ ovig., cl $4.0 \mathrm{~mm}$ (MNHN-IU-2018-252) and $4.4 \mathrm{~mm}$ (MNHN-IU-2018-253), same data as for preceding. - Mahnd river (Station 10): 2 $\widehat{\jmath}, \mathrm{cl} 2.9 \mathrm{~mm}(\mathrm{MNHN}-\mathrm{IU}-2018-254)$ and $3.3 \mathrm{~mm}$ (MNHN-IU-2018-255), 06 ${ }^{\circ} 50.221^{\prime} \mathrm{N}, 158^{\circ} 17.212^{\prime}$ E, 107 m a.s.1., 14 Mar. 2012; 1 ㅇ ovig., cl. $4.3 \mathrm{~mm}$ (MNHN-IU-2018-256), same data as for preceding. 

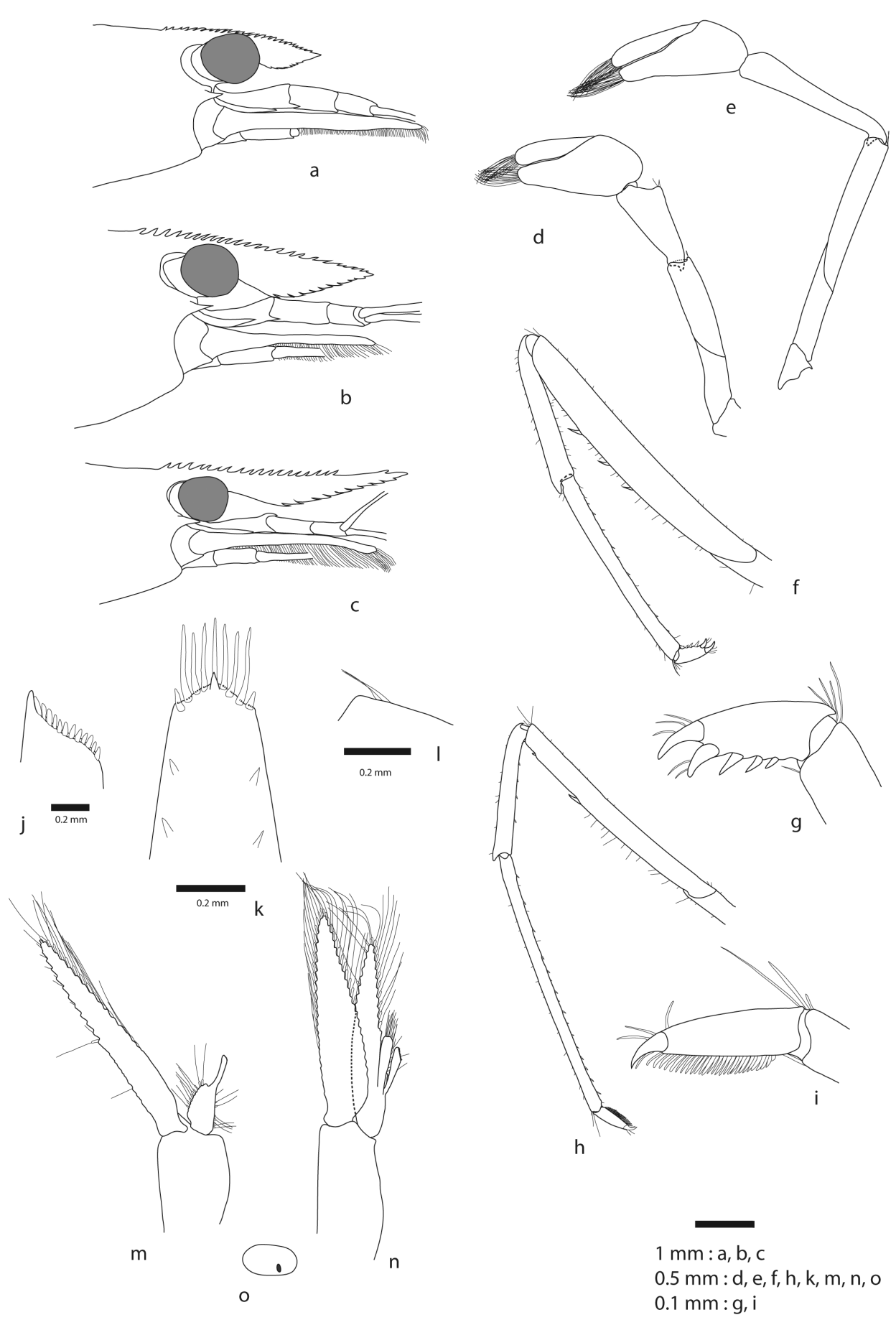

Fig. 3. Caridina variabilirostris sp. nov., showing the variation in rostrum length related to the altitude (ac), drawings made from different specimens. a, m-n. Oे $^{2} \mathrm{cl} 3.5 \mathrm{~mm}$ (MNHN-IU-2018-244). a. Rostrum. m. First pleiopod. n. Second pleiopod. b. $\circ$, cl 5.6 mm, rostrum (MNHN-IU-2018-252). c, j, o. cl 4.0 mm (MNHN-IU-2018-253) c. Rostrum. j. Uropodial diaeresis. o. Eggs. d-i, k. + , cl 3.5 mm (MNHN-IU-2018-250). d. First pereopod. e. Second pereopod. f. Third pereopod. g. Dactylus of third pereopod. h. Fifth pereopod. i. Dactylus of fifth pereopod. k. Telson. 1. ㅇ, cl $4.3 \mathrm{~mm}$, pre-anal carina (MNHN-IU-2018-256). of third pereopod. h. Fifth pereopod. i. Dactylus of fifth pereopod. k. Telson. l. + , cl $4.3 \mathrm{~mm}$, pre-anal carina (MNHN-IU-2018-256). 


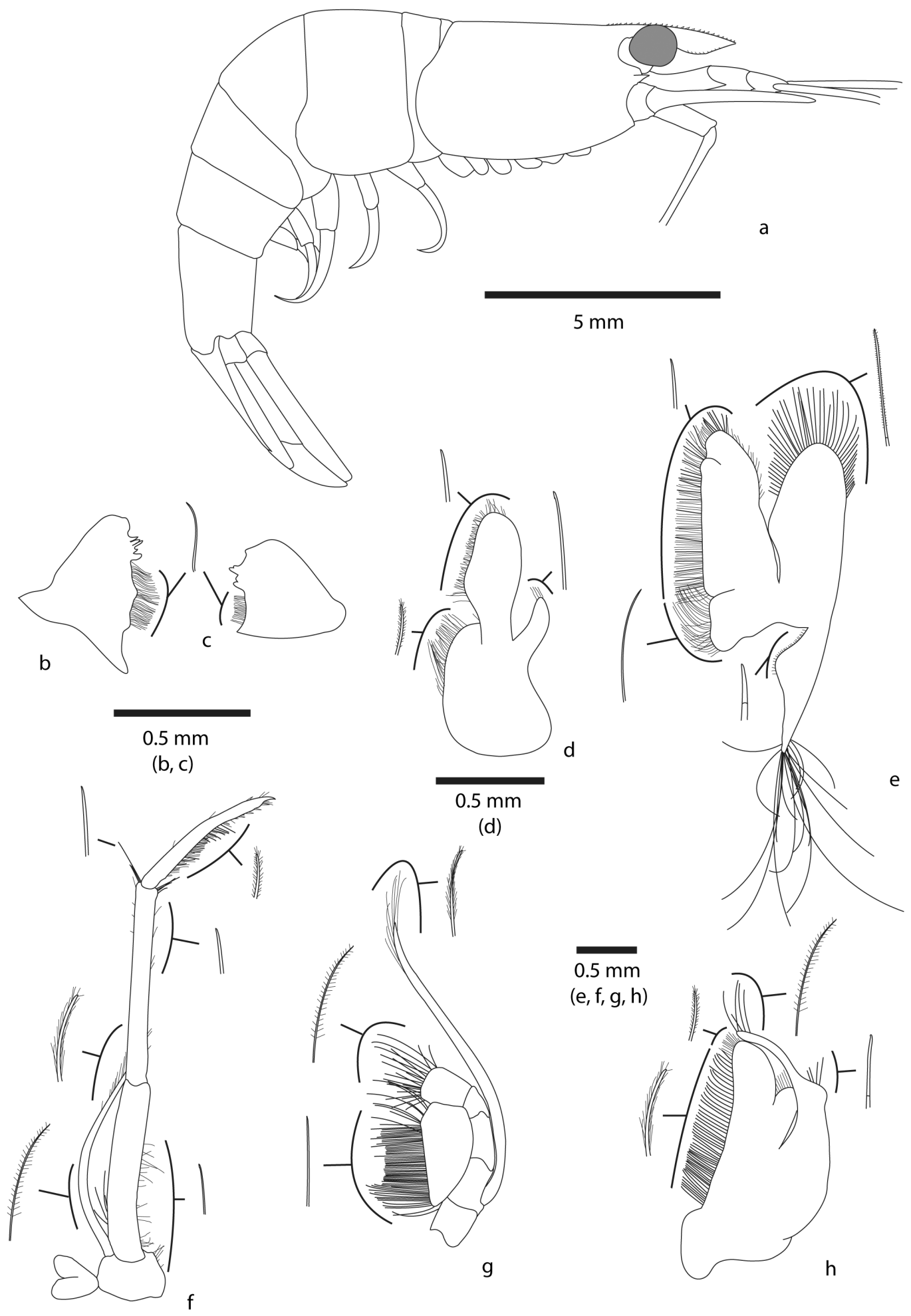

Fig. 4. Caridina variabilirostris sp. nov., showing drawings made from different specimens: a. $\hat{\partial}$, cl $3.5 \mathrm{~mm}$, general appearance (MNHN-IU-2018-244). c-d. + , cl $3.5 \mathrm{~mm}$ (MNHN-IU-2018-250). c. Right mandible. d. First maxilla. b, e-h. + , cl 4.8 mm, (MNHN-IU-2018-238). b. Left mandible. e. Second maxilla. f. Third maxilliped. g. Second maxilliped. h. First maxilliped. 


\section{Comparative material}

\section{Caridina brachydactyla De Man, 1908}

\section{Lectotype}

INDONESIA: 1 q ovig., cl 4.8 mm, Flores, Reo (RMNH Crus.D.977).

\section{Paralectotypes}

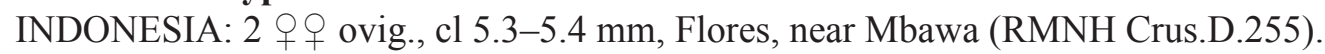

\section{Non types}

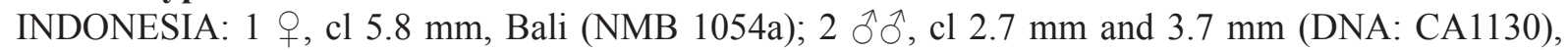
Sulawesi, Palopo, Macaui (WK 63.10); 2 q ㅇ ovig., cl $4.3 \mathrm{~mm}$ (DNA: CA1129) and $4.0 \mathrm{~mm}$ (DNA: CA1131), and 1 , , cl 4.8 mm, Palopo, Tojo (WK 64.10).

\section{Caridina mertoni Roux, 1911}

\section{Syntypes}

INDONESIA: $2 \hat{\jmath}, \mathrm{cl} 2.7 \mathrm{~mm}$ and $3.8 \mathrm{~mm}$ (DNA: CA056) and 1,$+ \mathrm{cl} 4.1 \mathrm{~mm}$ (DNA: CA058), Grand Kai, Elat (NMB 693a); 1 ${ }^{\lambda}$, cl $3.1 \mathrm{~mm}$ and 1 \% ovig., cl 4.8 mm, Grand Kai, Warka (NMB 693b); 1 , cl 4.3 mm (DNA: CA046), Grand Kai, Enralang, (NMB 693c); 1 ô, cl 3.8 mm, Grand Kai, Elat (MNHNIU-2015-1819); 1 đ, cl 3.4 mm, Grand Kai, Elat (MNHN-IU-2015-1820).

\section{Non types}

KOLOMBANGARA (SOLOMON ISLANDS) - Manolu river: 1 ô, cl $3.9 \mathrm{~mm}, 08^{\circ} 05.312^{\prime} \mathrm{S}$, 15700.813' E, 10 Nov. 2015 (MNHN-IU-2017-2107, DNA: CA1506); 1 ô, cl 3.0 mm, same data as for preceding (MNHN-IU-2017-2108, DNA: CA1507); 1 ô, cl $3.7 \mathrm{~mm}$, same data as for preceding (MNHN-IU-2017-2109, DNA: CA1505); 1 o ovig., cl $3.9 \mathrm{~mm}$, same data as for preceding (MNHNIU-2017-2110). - Sulumuni river: 1 क , cl $6.2 \mathrm{~mm}, 08^{\circ} 02.253^{\prime} \mathrm{S}, 157^{\circ} 09.257^{\prime} \mathrm{E}, 12$ Nov. 2015 (MNHN-IU-2017-2111, DNA: CA1514); 1 o ovig., cl $4.1 \mathrm{~mm}$, same data as for preceding (MNHNIU-2017-2112, DNA: CA1517).

\section{Non types}

Caridina elongapoda Liang \& Yan, 1977

HONG-KONG: 2 ふ઼ે, cl 2.8-3.5 mm, Pak Tam Chung, W. Klotz leg. (WK 22 09); 1 + , cl 4.2 mm and 1 ภ̊, cl 3.5 mm, Kai Sai Chau, W. Klotz leg. (WK 14 11).

MALAYSIA: 1 ð̊, cl 4.2 mm, Pulau Tioman, Sungai Asah, 24 Jun. 1997, Ng et al. leg. (ZRC 1998.0865); 1 q, cl $4.3 \mathrm{~mm}$, same data as for preceding (ZRC 1998.0865); 1 q ovig., cl $4.3 \mathrm{~mm}$, same data as for preceding (ZRC 1998.0865).

\section{Lectotype}

\section{Caridina peninsularis Kemp, 1918}

MALAYSIA: 1 đ̊, cl 3.2 mm, Penang Island, Botanical garden, Feb. 1916, N. Anandale leg. (MNHNIU-2015-1749).

\section{Paralectotypes}

MALAYSIA: 1 ovig., cl $5.4 \mathrm{~mm}$, same data as lectotype (MNHN-IU-2015-1750); 1 q, cl $3.4 \mathrm{~mm}$, same data as for preceding (NHM 1919.11.1.12-21 (1761124)); 1 q ovig., cl $5.2 \mathrm{~mm}$, same data as for preceding (NHM 1919.11.1.12-21 (1761124)); 1 ô, cl $3.9 \mathrm{~mm}$, same data as for preceding (NHM 1919.11.1.12-21 (1761124)). 
Non types

SINGAPORE: 1 + ovig., cl $5.1 \mathrm{~mm}$, Tanglin (incorrectly spelt "Tangtum" in NHM register and on label, see Richard \& Clark 2014), 1958 Bedford and Lanchester leg., D.S. Johnson det. (NHM 1958.8.7.14-17 (1749569)); 1 त, cl $4.2 \mathrm{~mm}$, same data as for preceding (NHM 1958.8.7.14-17 (1749569)).

\section{Description}

Cephalothorax. Rostrum (Fig. 3a-c): very variable in length, $0.6-1.3 \mathrm{of} \mathrm{cl}$, reaching to scaphocerite apex, armed dorsally with 18-26 teeth, distal unarmed portion $0.0-0.4$ times that of armed portion, with one or two subapical teeth, 1-4 teeth on carapace posterior to orbital margin, ventral margin with 4-12 teeth. Number of dorsal teeth behind most proximal ventral tooth 12-18. Rostrum formula (1-4) 18-26+1-2/4-12. Antennular tooth acute, placed slightly below orbital angle. Pterygostomian margin rectangularly rounded.

HEAD. Eyes well developed, anterior end reaching to 0.7 length of antennular peduncle basal antennomere. Antennular peduncle 0.7 times as long as carapace. Anterolateral angle reaching 0.25 length of second antennomere; second antennomere distinctly longer than third. Stylocerite reaching to 0.7 length of antennular peduncle basal antennomere.

MOUTHPARTS. Mandibles dimorphic; left mandible (Fig. 4b) more developed, corpus large, robust with five strong sharp teeth separated by ridged gap; incisor and molar processes separated by patch of long simple setae. Right mandible (Fig. 4c) with five sharp incisor teeth, medially with group of long setae; molar process narrow, elongate, ridged. First maxilla (Fig. 4d) having a lower lacinia with margin broadly rounded, bearing several rows of plumose setae. Upper lacinia elongate, with medial margin bearing a number of distinct teeth and simple setae, palp bearing long simple setae. Second maxilla (Fig. 4e) upper and middle endite with marginal and submarginal simple or slightly plumose setae. Lower endite with simple setae; palp narrow, shorter than upper endite cleft with few setae. Scaphognathite fringed with long simple setae, tapering posteriorly with some long, curved simple setae at posterior end. First maxilliped (Fig. 4h) endopodite ultimate segment medial margin with long plumose setae. Palp elongate, setose. Exopod flagellum long and narrow distally with marginal plumose setae. Caridean lobe large, with marginal setae. Second maxilliped (Fig. 4g) endopodite ultimate and penultimate antennomeres fused, reflected against basal antennomeres. Ultimate, penultimate and basal antennomeres medial margins with long setae of various types; flagellum very long, slender with marginal plumose setae distally. Third maxilliped (Fig. 4f) with terminal article reaching third antennular peduncle antennomere apex; distal antennomere about 10 times as long as wide, slightly shorter than penultimate, ending in large hamulate apical spine surrounded by simple setae. Penultimate antennomere about eight times as long as wide, with group of transverse rows of simple setae. Exopod flagellum well developed, about a third the length of endopodite second article, distal margin with long plumose setae.

Pereopods. Pereopods I-IV with epipods pereopod. P1 (Fig. 3d): chela about 1.9-2.2 times as long as wide, movable finger 3.6-4.4 times as long as wide, 1.2-1.7 times length of palm; carpus 2.0-2.7 times as long as wide. P2 (Fig. 3e) more slender and longer than first pereopod with chela 2.1-2.6 times as long as wide: movable finger 3.9-5.8 times as long as wide, 1.3-2.0 times length of palm; carpus slender 4.4-6.5 times as long as wide. P3 (Fig. 3f): slender, dactylus (Fig. 3g) 2.4-3.3 times as long as wide, including terminal spine), flexor margin with 4-6 spines parallel to terminal one; propodus 13.8-20.5 times as long as wide, 4.8-8.4 times as long as dactylus. P5 (Fig. 3h): dactylus (Fig. 3i) 2.1-4.2 as long as wide with 18-29 spinules on flexor margin; propodus 15.8-28.4 times as long as wide, 5.3-8.6 times as long as dactylus.

AbDomen. Third abdominal (Fig. 4a) somite with moderately convex dorsal profile. Sixth abdominal somite about 0.68 of carapace, 1.76 times as long as fifth somite, slightly shorter than telson. Telson 
(Fig. 3k) with four pairs of dorsal spines and one pair of dorsolateral spines; posterior margin, with or without median process, exhibits variations, triangular or rounded with four to five intermediate simple setae longer or equal than lateral ones.

PL1 (Fig. 3m). Endopod foliform with a developed appendix interna in males. P12 (Fig. 3n): appendix masculina on second pleopod reaching 0.52 times length of endopod; appendix interna reaching about 0.85 times appendix masculina length.

Preanal Carina (Fig. 31). Unarmed.

Uropodal diaeresis (Fig. 3j). With 10-15 spinules.

Ovigerous female EgG Size (Fig. 3o). 0.39-0.49x0.24-0. $29 \mathrm{~mm}$.

\section{Habitat}

This species is found among macrophytes in flowing fresh water of the rivers of Pohnpei all along the course, showing good adaptability to different temperatures and hydrological conditions. It is more abundant in higher elevations due to reduced predator pressure.

\section{Colour pattern (Fig. 5)}

The colour of the body is hyaline with many reds dots. An oblique red band on the cephalothorax is very characteristic.
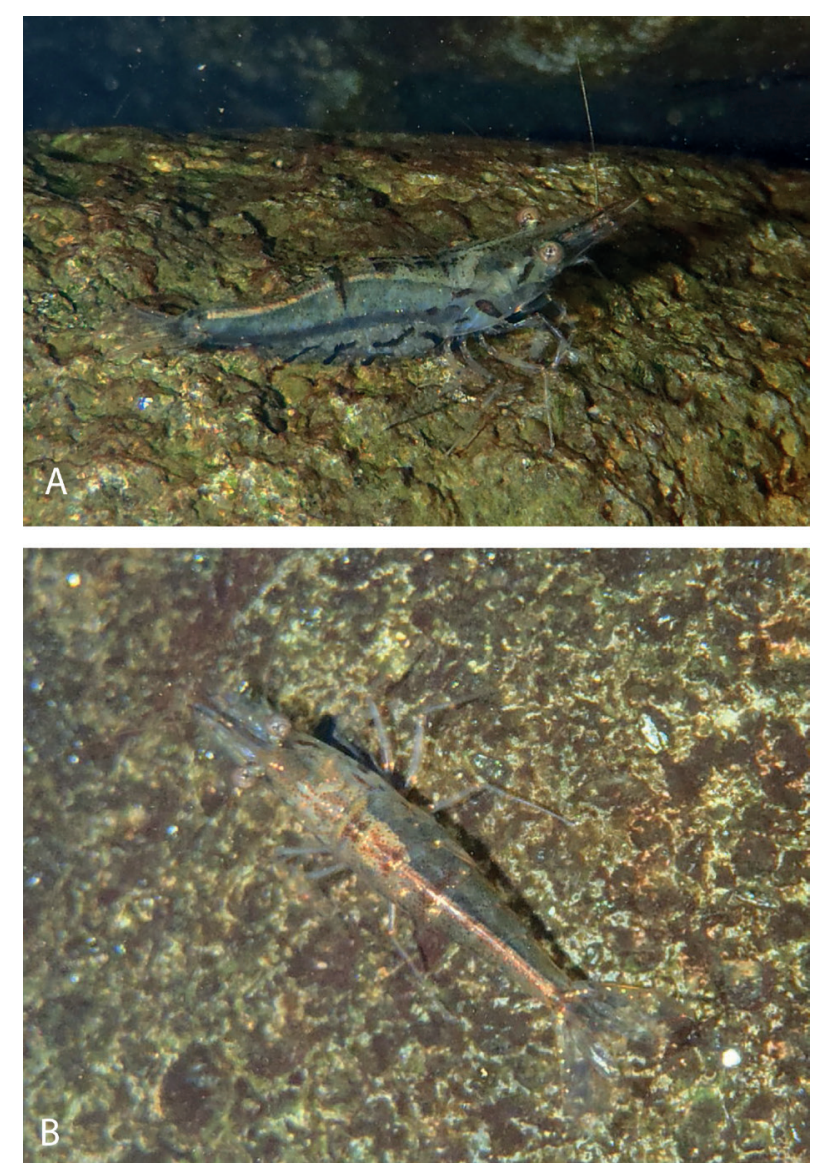

Fig. 5. Caridina variabilirostris sp. nov., live coloration (Photos: P. Keith) 


\section{Distribution}

This new species is currently known from Pohnpei Island only.

\section{Remarks}

Caridina variabilirostris sp. nov. is most similar to C. mertoni, C. brachydactyla, C. elongapoda Liang \& Yan, 1977 and C. peninsularis Kemp, 1918. The new species displays a variable rostrum length among specimens. When the rostrum is short the general appearance is like C. mertoni, whereas when the rostrum is long, the general appearance is of C. brachydactyla. In C. variabilirostris spec. nov. the antennal spine is placed below the orbital angle, the P5 dactylus with 18-29 spinules whereas in C. mertoni, the antennal spine is somewhat fused with the orbital angle and P5 dactylus with 24-43 spinules. C. variabilirostris spec. nov. differs from C. brachydactyla by the absence of spine on the preanal carina, a shorter distal unarmed portion of the rostrum 0.0-0.4 (vs 0.4-1.6) times that of armed portion, by a longer P5 propodus, which is 5.3-8.6 time as long as the dactylus (vs 3.9-5.7) and a lower number of spinules on the P5 dactylus (32-42 in C. brachydactyla).

This new species resembles C. elongapoda in its preanal carina lacking a spine, but it has larger eggs $0.39-0.49 \times 0.24-0.29 \mathrm{~mm}$ (vs $0.39-0.40 \times 0.22-0.23$ ), and the P5 dactylus is shorter 2.1-4.2 (vs 4.35.6) and with fewer spinules 18-29 (vs 33-44). It also differs from C. peninsularis by a lower number of dorsal rostrum teeth (18-26 vs 20-35), a lower P3 propodus-dactylus ratio (4.8-8.4 vs 4.4-5.8) and a P5 dactylus with $18-29$ spinules vs $25-38$.

The new species looks very much like $C$. variabilis from Guam and Palau with the preanal always nonarmed, the number of teeth and their placement on the rostrum, the proportions between the joints of pereiopods, and the egg size (Mazancourt et al. 2018). But the P5 dactylus has a single terminal spine and a short distal propodus seta (vs two strong distal spines and a very long distal propodus seta), and the posterior margin of the telson with intermediate setae longer or equal than lateral ones (vs shorter or equal than lateral ones).

\section{Discussion}

Recently Mazancourt et al. (2017) highligted the "Pinocchio shrimp effect" on this new species. Indeed some specimens with a long rostrum were attributed morphologically to C. brachydactyla whereas others, with a short rostrum, were identified as $C$. mertoni. In fact all specimens belong to this new species. Indeed the rostrum length widely used in the taxonomy of Caridina might not be as reliable as it was thought. It is highly plastic and varies with environmental parameters.

Despite an increasing use of integrative taxonomy for the systematics of Caridina (and shrimps in general), some authors keep describing new species based not only on morphology alone, but even on a single character. For example, different species described by Richard \& Clark $(2009,2014)$ based on rostrum morphology proved to be synonyms, and the differences observed were after all recognized as intra-specific variation (see Wood et al. 2018; Mazancourt et al. unpublished).

We thus advocate to always perform some molecular work prior to studying a new species in order to unveil this kind of variation within a species, focus on the morphology and expose the variation when describing it. Alternatively, if retrieving molecular data is not possible, using a combination of reliable characters seems more sound than a single one. This would allow to provide characters to identify confidently the species when encountered in the field. It is likely that different species described in this genus will prove to be the same one, exhibiting the same kind of polymorphism as we showed here. 


\section{Acknowledgements}

We would like to thank The Conservation Society of Pohnpei and particularly Eugene Joseph (Director), Francesca Sohl Obispo, Relio Lengsi and Iakop loanis, and the Office of fisheries and aquaculture for their help with processing the research permits. Brian Lynch was an incredible source of knowledge on the biodiversity of Pohnpei. He also facilitated the organisation of various meetings with a number of local stakeholders, including assistance with some aspects of the logistics in the field. Finally, a special thought to P. Gerbeaux, M. Castelin and L. Taillebois.

The work was supported by the National Museum of Natural History of Paris, the AIMARA Association and the French Ichthyological Society.

\section{References}

Buden D.W., Lynch D.B., Short J.W. \& Leberer T. 2001. Decapod crustaceans of the headwater streams of Pohnpei, eastern Caroline Islands, Federated States of Micronesia. Pacific Science 55 (3): 257-265. https://doi.org/10.1353/psc.2001.0019

Coleman C.O. 2003. "Digital inking": How to make perfect line drawings on computers. Organisms Diversity and Evolution 3 (4): 303-304. https://doi.org/10.1078/1439-6092-00081

Coleman C.O. 2006. Substituting time-consuming pencil drawings in arthropod taxonomy using stacks of digital photographs. Zootaxa 1360: 61-68.

Covich A.P., Palmer M.A. \& Crowl T.A. 1999. The role of benthic invertebrate species in freshwater ecosystems. BioScience 49 (2): 119-128. https://doi.org/10.2307/1313537

De Grave S., Smith K.G., Adeler N.A., Allen D.J., Alvarez F., Anker A., Cai Y., Carrizo S.F., Klotz W., Mantelatto F.L., Page T.J., Shy J.Y., Villalobos J.L. \& Wowor D. 2015. Dead shrimp blues: a global assessment of extinction risk in freshwater shrimps (Crustacea: Decapoda: Caridea). PLoS ONE 10 (3): e0120198. https://doi.org/10.1371/journal.pone.0120198

Edgar R.C. 2004. MUSCLE: multiple sequence alignment with high accuracy and high throughput. Nucleic Acids Research 32 (5): 1792-1797. https://doi.org/10.1093/nar/gkh340

Felsenstein J. 1985. Confidence limits on phylogenies: an approach using the bootstrap. Evolution 39: 783-791. https://doi.org/10.1111/j.1558-5646.1985.tb00420.x

Kearse M., Moi R., Wilson A., Stones-Havas S., Cheung M., Sturrock S., Buxton S., Cooper A., Markowitz S., Duran C., Thiere T., Ashton B., Meintjes P. \& Drummond A. 2012. Geneious Basic: an integrated and extendable desktop software platform for the organization and analysis of sequence data. Bioinformatics 28 (12): 1647-1649. https://doi.org/10.1093/bioinformatics/bts 199

Keith P., Gerbeaux P., Marquet G., Taillebois L. \& Castelin, M. 2012. Freshwater Survey of Pohnpei. Muséum national d'Histoire naturelle, Paris.

Kumar S., Stetcher G. \& Tamura K. 2016. MEGA7: Molecular Evolutionary Genetics Analysis Version 7.0 for Bigger Datasets. Molecular Biology and Evolution 33 (7): 1870-1874. https://doi.org/10.1093/molbev/msw054

Leberer T. \& Cai Y. 2003. Shrimps of the family Atyidae from Guam, Mariana Islands. Micronesica, 35-36: 353-358.

Maciolek J.A. \& Ford J.L. 1987. Macrofauna and Environment of the Nanpil-Kiepw River, Ponape, Eastern Caroline Islands. Bulletin of Marine Science 41 (2): 623-632. 
Mazancourt V. de, Marquet G. \& Keith P. 2017. The "Pinocchio-shrimp effect": first evidence of rostrum length variation with the environment in Caridina H. Milne Edwards, 1837 (Crustacea: Decapoda: Atyidae). Journal of Crustacean Biology 37 (3): 249-257. https://doi.org/10.1093/jcbiol/rux025

Mazancourt V. de, Marquet G., Rogers D.C. \& Keith P. 2018. Description of a new species of Caridina (Crustacea: Decapoda: Atyidae) from two Micronesian islands (Guam and Babeldaob). Zootaxa 4377 (1): 39-50. https://doi.org/10.11646/zootaxa.4377.1.3

Miller M., Pfeiffer W. \& Schwartz T. 2010. Creating the CIPRES Science Gateway for Inference of Large Phylogenetic Trees. http://www.phylo.org/sub_sections/portal/sc2010_paper.pdf

Nelson S.G., Camacho F.A., Parham J.E., Tibbats R.B., Leberer T. \& Smith B.D. 1996. Surveys of the macrofauna of the Nanpil Kiepw and Lehn Mesi rivers of Pohnpei. South Pacific Regional Environment Programme. Technical Report 103. University of Guam Marine Laboratory.

Page T.J. \& Hughes J.M. 2011. Neither molecular nor morphological data have all the answers; with an example from Macrobrachium (Decapoda: Palaemonidae) from Australia. Zootaxa 2874: 65-68.

Page T.J., Choy S.C. \& Hughes J.M. 2005. The taxonomic feedback loop: symbiosis of morphology \& molecules. Biology Letters 1: 139-142. https://doi.org/10.1098/rsbl.2005.0298

Page T.J., Rintelen K. von \& Hughes J.M. 2007. An island in the stream: Australia's place in the cosmopolitan world of Indo-West Pacific freshwater shrimp (Decapoda: Atyidae: Caridina). Molecular Phylogenetics and Evolution 43: 645-659. https://doi.org/10.1016/j.ympev.2006.08.007

Palumbi S.R. 1996. Nucleic acids II: the polymerase chain reaction. In: D.M. Hillis, B.K. Mable \& C. Moritz (eds) Molecular systematics 205-247. Sinauer Associates, Sunderland, USA.

Pringle C.M., Blake G.A., Covich A.P., Buzby K.M. \& Finley A. 1993. Effects of omnivorous shrimp in a montane tropical stream: sediment removal, disturbance of sessile invertebrates and enhancement of understory algal biomass. Oecologia 93: 1-11. https://doi.org/10.1007/BF00321183

Rehman H.U., Nakaya H. \& Kawai K. 2013. Geological Origin of the volcanic islands of the Caroline Group in the Federated States of Micronesia, Western Pacific. South Pacific Studies 33 (2): 101-118.

Richard J. \& Clark P.F. 2009. African Caridina (Crustacea: Decapoda: Caridea: Atyidae): redescriptions of C. africana Kingsley, 1882, C. togoensis Hilgendorf, 1893, C. natalensis Bouvier, 1925 and C. roubaudi Bouvier, 1925 with descriptions of 14 new species. Zootaxa 1995: 1-75.

Richard J. \& Clark P.F. 2014. Caridina simoni Bouvier, 1904 (Crustacea: Decapoda: Caridea: Atyoidea: Atyidae) and the synonymy by Johnson, 1963. Zootaxa 3841 (3): 301-338.

https://doi.org/10.11646/zootaxa.3841.3.1

Rintelen K. von \& Cai Y. 2009. Radiation of endemic species flocks in ancient lakes: systematic revision of the freshwater shrimp Caridina H. Milne Edwards, 1837 (Crustacea: Decapoda: Atyidae) from the ancient lakes of Sulawesi, Indonesia, with the description of eight new species. Raffles Bulletin of Zoology 57: 343-452.

Ronquist F. \& Huelsenbeck J.P. 2003. MRBAYES 3: Bayesian phylogenetic inference under mixed models. Bioinformatics 19: 1572-1574. https://doi.org/10.1093/bioinformatics/btg180

Wood L.E., Daniels S.R. \& De Grave S. 2018. Caridina susuroflabra Richard \& Clark, 2009 is a junior synonym of the widespread Caridina africana Kingsley, 1882 (Decapoda, Atyidae). Crustaceana 91 (2): 243-249. https://doi.org/10.1163/15685403-00003756 
Manuscript received: 23 February 2018

Manuscript accepted: 21 June 2018

Published on: 3 August 2018

Topic editor: Rudy Jocqué

Desk editor: Eva-Maria Levermann

Printed versions of all papers are also deposited in the libraries of the institutes that are members of the EJT consortium: Muséum national d'Histoire naturelle, Paris, France; Botanic Garden Meise, Belgium; Royal Museum for Central Africa, Tervuren, Belgium; Natural History Museum, London, United Kingdom; Royal Belgian Institute of Natural Sciences, Brussels, Belgium; Natural History Museum of Denmark, Copenhagen, Denmark; Naturalis Biodiversity Center, Leiden, the Netherlands; Museo Nacional de Ciencias Naturales-CSIC, Madrid, Spain; Real Jardín Botánico de Madrid CSIC, Spain; Zoological Research Museum Alexander Koenig, Bonn, Germany. 